\title{
The Trends in Usage and Barriers of Innovation Management Techniques in New Product Development
}

\author{
Marjan Leber ${ }^{1}$ - Majda Bastič ${ }^{2}$ - Borut Buchmeister ${ }^{1, *}$ \\ ${ }^{1}$ University of Maribor, Faculty of Mechanical Engineering, Slovenia \\ 2 University of Maribor, Faculty of Economics and Business, Slovenia
}

\begin{abstract}
This paper reports the results of a survey on the use of innovation management techniques (IMTs) with the potential to improve effectiveness of new product development (NPD), and customer satisfaction as well as about those barriers preventing their introduction in Slovene firms in the period from 2003 to 2011. The results show that small percentage of Slovene firms used IMTs. Failure mode and effects analysis (FMEA) was found as the most applied IMT in Slovene firms with the highest perceived utility potential to reduce development costs and improve customer satisfaction. Results also indicate a trend towards the increasing use of fault tree analysis (FTA), value analysis, target costing, and TRIZ especially during the period of 2008 to 2011 which coincides with the period of economic and financial crisis. IMT complexity, a needed coaching and training and the lack of input data for IMT usage were recognized as the main barriers to implementing IMTs in Slovene firms.

Keywords: innovation management techniques, new product development, longitudinal study
\end{abstract}

\section{O INTRODUCTION}

Satisfying new customers' requirements regarding product quality and price presents an opportunity to firms to develop new products as well as the challenge for operational innovation and knowledge management. Innovative approaches are essential in successful product design (for new and modified existing products).

Innovations defined as the successful exploitation of new ideas are seen as "powerful engine" for firms' development that also influence social and global challenges [1] to [5]. Even in the years of economic instability it was often heard how innovations were important for the success of companies [6] to [9].

New product development (NPD) defined as the transformation of a new idea or a new market opportunity into a new product available for sale is risky and not easy [10]. With short time-tomarket, fierce competition in an already crowded market place, and ever-more demanding consumers, organizations must continually make trade-offs when identifying project priorities and allocating resources [11]. Cooper estimated that $46 \%$ of the resources that companies devote to the designing, developing, and launching of new products go into projects that fail in the market place or perhaps never even make it to market [12]. Barczak et al. found that only $14 \%$ of initial ideas actually become commercially successful. Therefore, it is vital that less promising ideas are filtered out as early as possible, but that promising ideas are not dissipated [13].

The effectiveness of NPD measured by time-tomarket, product and development cost, and product quality can be improved by usage of innovation management techniques (IMTs) [14] to [17]. Barczak et al. [13] found a significant difference in the use of these techniques in the best firms, and the rest. The best firms used large numbers of techniques more frequently, which suggests that they may be more open to experimenting with new tools and methodologies and to leveraging existing tools and methodologies for improving the efficiency and effectiveness of their innovation projects. Rihar et al. [18] presented the strengths of simultaneous product development and complete realisation from the initial idea to market presence.

Considering the impact of IMT usage on the NPD effectiveness and firms' success as well as the current situation of Slovene firms which are facing with consequences of economic and financial crisis the objective of this study was to analyse the usage and trends in IMT usage in Slovene firms, the IMT perceived utility in improving NPD effectiveness and the most important barriers which prevented the Slovene firms to use IMTs.

\section{INNOVATION MANAGEMENT TECHNIQUES}

IMTs can be seen as a range of tools, techniques and methodologies that help companies to adapt to circumstances and meet market challenges in a systematic way [19]. Numerous new IMTs, as well as appropriate software, have been developed for improving the NPD process and reducing the uncertainty of NPD outcomes [20]. The growth of IMTs results from a new way of thinking. It is not necessarily due to technology, but more to the 
capacity of firms to apply their knowledge to improve businesses internally and their relationships with external actors [21].

Palacios \& Gonzáles classified the IMTs into five generic categories [22]:

- Design techniques: quick product specification, quality function deployment, conjoint analysis, design for excellence, robust design modular design, incremental innovation, rapid design transfer, group technology, rapid prototyping and tooling, failure mode effect analysis;

- Organizational techniques (concurrent activities management, stage-gate process, multifunctional design teams);

- Manufacturing techniques, (manufacturing resource planning, just in time, optimal product technology, statistical process control);

- Information techniques (computer aided design, computer aided manufacturing, computer aided engineering, computer integrated manufacturing, internet and intranets, electronic data interchange, expert systems, groupware, and product data management); and

- Supplier involvement.

These techniques can be applied to timely experiment a number of product and process options that are available or feasible [14]. They must empower teams at all levels of organizations by giving them timely information for making timely decisions, before tasks become critical [23] to [25].

Successful implementation and utilization of IMTs calls for a holistic view of all aspects of the NPD process, the specific tasks or techniques, the types of information and knowledge to be processed and the people who are supposed to use them [20]. In addition, it is essential to carefully select and match the right IMT with the right task and phase of the NPD process.

A lack of qualified personnel with experience in IMTs has been the reason for non-use of IMT. Most SMEs do not have the necessary in-house knowledge of IMTs and their implementation [21].

Our study deals with two major questions:

- Does innovation management technique usage contribute (support) the NPD in Slovene firms?

- Can Slovene firms improve innovation processes using innovation management techniques?

\section{METHODOLOGY}

The study carried out in 2011 was part of longitudinal survey started in 2003. The questionnaire applied during the 2011 survey was 16 pages in length and covered the following issues:

- background information on the respondents;

- the main reasons which initiated NPD;

- competences and frequency of IMT usage;

- the perceived utility potential of IMTs to NPD effectiveness;

- barriers to IMT usage in NPD.

The questions about percentages of firms using IMTs and the IMT utility potential were worded identically as in the 2003 survey. The sections: the importance of reasons influencing the start of an NPD, percentage of Slovene firms with IMT competence and the frequency of IMTs use, were completely new. The informants were top managers or product development managers as it was assumed that they best know the innovation processes in their firms.

The 2003 survey was an exploratory study based on a sample of 19 firms. Either personally or by e-mail all 15 still operating firms participating in the 2003 survey were contacted in 2011. In addition, we invited also similar firms to participate in the survey in order to increase sample size and improve the reliability of the obtained results. The invitation for participating in this study was provided by The Chamber of Commerce and Industry of Slovenia website home page. The questionnaires were completed between March and April 2011. As the financial and economic crisis started in the year 2008 had changed the business environment, changes in IMT usage were of interest in the period from 2008 to 2011. Therefore, the respondents were asked to provide data on IMT use in the years 2008 and 2011.

Completed questionnaires were received from 40 firms, three questionnaires were unusable. 15 usable questionnaires were from firms participating in the 2003 survey. The potential reasons for the low response rate could be the length of the questionnaire and the numerous questionnaires Slovene firms obtain almost every day. The same problems have also been noticed in the similar studies [22] and [26].

The majority of the firms in sample operated in the metal processing industry $(45.9 \%)$ followed by service firms $(18.9 \%)$, and the electro industry $(13.5 \%)$. The remainder of the firms belonged to the chemical, textile, and other industries. Regarding firms' size $31.4 \%$ were small firms, $34.3 \%$ mediumsized, and $34.3 \%$ were large firms. $75 \%$ of the firms were profitable. The firms were also asked about their most important strategic objective. $15.2 \%$ of the firms reported cost reduction, $27.2 \%$ quality improvement of existing products or services, and $57.6 \%$ the development of new products or services. 
The following IMTs that were often cited in the literature and were known to respondents in the 2003 survey were included in 2011 survey. They were classified into three groups:

- Idea generation and screening: delphi method (DM), theory of inventing problem solving (TRIZ);

- Design techniques: conjoint analysis (CA), fault tree analysis (FTA), failure mode and effects analysis (FMEA), design of experiment (DoE), quality function deployment (QFD), value analysis (VA), target costing (TC);

- Manufacturing techniques: statistical process control (SPC).

CA, QFD, DoE, DM are known as IMTs that contribute to a reduction in time-to-market. Development costs could be successfully planned and controlled using TC, VA, and TRIZ. Customer satisfaction could be improved using CA, FMEA, QFD and VA. FMEA and FTA are known as the best tools to foster expert teams to perpetuate the voice of the customer and engineer throughout the product development cycle so that QFD is the guardian to the voice of customer while FMEA is the guardian to the voice of the engineer [27].

Although we attempted to overcome some of the methodological problems, some caveats also apply to this research. Firstly, the results must be considered exploratory by nature because of the sources employed in our research. A second concern about the study was that all the data were collected from a single respondent from each firm. While the respondents were shown to possess high degrees of relevant knowledge, they were still subject to respondent bias. Due to the small sample, it was impossible to draw any representative conclusions for this subset of firms using IMTs in innovation processes. However, an initial impression of the methodology used can be obtained. Further studies with larger samples would clarify the picture.

\section{RESULTS}

\subsection{Reasons Triggering the NPD}

In the first step of the survey, we analysed the importance of reasons which initiated an innovation process in Slovene firms. The questionnaire included the following reasons: creating a competitive advantage, the development of new package, an improvement of product quality by incremental changes, an improvement of product quality by radical changes, the development of a new product in the word, the development of a new product in the firm, better meeting customers' requirements. The respondents estimated the importance of these reasons on a 10-point scale ranging from 1 - 'not at all important' to 10 - 'very important'.

Table 1. The importance of reasons influencing the start-up of innovation process

\begin{tabular}{lll}
\hline The reason & 2008 & 2011 \\
\hline Competitive advantage & 6.04 & 7.17 \\
\hline Development of new package & 2.90 & 3.10 \\
\hline Incremental changes of a product & 7.04 & 7.24 \\
\hline Radical changes of a product & 6.54 & 7.33 \\
\hline New-to-the world product & 5.81 & 5.89 \\
\hline New-to-the firm product & 5.39 & 6.50 \\
\hline Customers' requirements & 7.59 & 7.92 \\
\hline
\end{tabular}

Customers' requirements were found as the most important reason which triggered NPD processes in Slovene firms. They were followed by the improvement of product quality by incremental changes in 2008 and the improvement of product quality by radical changes in 2011 (see Table 1). The trend of increasing importance of all reasons was also noticed.

\subsection{Firms' Competences Regarding Innovation Management Techniques}

More than half of the sampled Slovene firms chose the development of new products as their main strategic goal. To efficiently achieve this goal a high effectiveness and efficiency of NPD processes have been requested. They can be improved by a methodological know-how within the firm. For this reason, we inquired about the IMT competences in Slovene firms.

Table 2. The percentages of Slovene firms with competences in IMTs (multiple answers were possible)

\begin{tabular}{lcc}
\hline Innovation management techniques & 2008 & 2011 \\
\hline CA & 5.0 & 2.5 \\
\hline FTA & 25.0 & 35.0 \\
\hline FMEA & 37.5 & 40.0 \\
\hline DoE & 10.0 & 12.5 \\
\hline QFD & 17.5 & 22.5 \\
\hline VA & 25.0 & 30.0 \\
\hline TC & 12.5 & 25.0 \\
\hline SPC & 27.5 & 25.0 \\
\hline TRIZ & 7.5 & 25.0 \\
\hline DM & 7.5 & 10.0 \\
\hline
\end{tabular}


The figures in Table 2 indicate that the competences in Slovene firms were different across the IMT spectrum. The majority of Slovene firms (37.5\%) had competences in FMEA followed by SPC $(27.5 \%)$ and FTA $(25 \%)$ in 2008. In 2011, the most popular was again FMEA $(40 \%)$ followed by FTA (35\%) and QFD (22.5\%). The share of firms with competence in CA was very low. In 2011, the increase in the percentage of Slovene firms with competence in FMEA and FTA was noticed on one hand and a decrease in SPC and CA on the other hand. In addition, an enormous increase in the percentages of firms with competences in TRIZ and target costing in 2011 was found.

\subsection{The Implementation of IMTs}

In addition to competences, we investigated the use of IMTs during the period from 2003 to 2011.

Table 3. The percentages of firms using IMTs (multiple answers were possible)

\begin{tabular}{lccc}
\hline Innovation management techniques & 2003 & 2008 & 2011 \\
\hline CA & 0.5 & 2.7 & 0 \\
\hline FTA & 13.0 & 21.2 & 29.7 \\
\hline FMEA & 38.0 & 35.1 & 37.8 \\
\hline DoE & 4.0 & 8.1 & 8.1 \\
\hline QFD & 12.0 & 13.5 & 13.5 \\
\hline VA & 18.0 & 24.3 & 27.0 \\
\hline TC & 8.5 & 10.8 & 16.2 \\
\hline SPC & 34.0 & 27.0 & 27.0 \\
\hline TRIZ & 0 & 5.4 & 8.1 \\
\hline DM & 0 & 0 & 2.7 \\
\hline
\end{tabular}

The figures in Table 3 show that more than $60 \%$ of Slovene firms did not use individual IMTs. In 2003, the most applied IMT was FMEA followed by SPC and VA. The rank order of the most applied IMTs did not change in the year 2008. In 2011, the majority of firms (37.8\%) used FMEA followed by FTA (29.7\%), VA (27\%), and TC (27\%). The very small percentage of Slovene sampled firms used AC and DM. A comparison of the data about IMTs usage between 2003 and 2011 showed stability in the percentages of firms using FMEA and QFD, a decline in the use of SPC and CA, and an increase in the use of other IMTs as presented in Table 3. The highest increase in the IMT usage was found for FTA $(16.7 \%)$, followed by VA $(9 \%)$, TRIZ $(8.1 \%)$, and TC $(7.7 \%)$.

We also analysed the difference in the frequency of IMT usage between profitable and non-profitable Slovene firms in 2008 and 2011 (See Table 4). The frequency of IMT usage was measured on a 10-point scale ranging from 1 - 'never used' to 10 - 'always used'. In 2008 and 2011 the profitable firms used all IMTs except TC in 2011 more frequently than the non-profitable firms. The most frequently used IMT in profitable firms was FMEA while non-profitable firms preferred SPC in 2008 and target costing in 2011.

Table 4. The frequency of IMT usage with respect to firms' profits

\begin{tabular}{lcccc}
\hline \multirow{2}{*}{$\begin{array}{l}\text { Innovation } \\
\text { management }\end{array}$ techniques } & \multicolumn{4}{c}{ Firm's profit } \\
\cline { 2 - 5 } & \multicolumn{3}{c}{2008} & \multicolumn{2}{c}{2011} \\
\cline { 2 - 5 } & Yes & No & Yes & No \\
\hline CA & 1.50 & 1.00 & - & - \\
\hline FTA & 4.00 & 2.00 & 5.00 & 1.67 \\
\hline FMEA & 7.00 & 3.40 & 6.92 & 4.00 \\
\hline DoE & 2.67 & 1.67 & 2.86 & 1.00 \\
\hline QFD & 4.29 & 2.00 & 3.67 & 3.67 \\
\hline VA & 5.30 & 2.33 & 6.50 & 4.25 \\
\hline TC & 4.43 & 1.33 & 4.33 & 4.50 \\
\hline SPC & 5.38 & 5.20 & 6.82 & 1.00 \\
\hline TRIZ & 3.17 & 1.00 & 2.78 & 1.50 \\
\hline DM & 1.00 & 1.00 & 1.67 & 1.00 \\
\hline & & & &
\end{tabular}

\subsection{Utility Potential of IMT and Barriers to Their Usage}

Table 5 gathers information on the perceived utility potential of IMTs for the years 2008 and 2011. In the 2003 analysis, the respondents were asked to choose one out of four areas where their experience shows the highest utility potential of IMTs: shorter development time (SDT) $13 \%$, failure cost reduction (FCR) 39\%, improvement of customer satisfaction (ICS) $40 \%$, knowledge management (KM) $8 \%$. The IMT utility potential in 2008 and 2011 were measured on a 10 -point scale ranging from 1 - 'no utility potential' to 10 - 'very high utility potential'.

Table 5. Utility potential of innovation management techniques

\begin{tabular}{lll}
\hline Utility potential & 2008 & 2011 \\
\hline SDT & 4.85 & 6.20 \\
\hline FCR & 6.15 & 7.35 \\
\hline ICS & 7.76 & 9.00 \\
\hline KM & 5.65 & 6.95 \\
\hline
\end{tabular}

As can be seen in Table 5, respondents did not perceive low utility potential of IMTs. Therefore, this finding does not explain the low percentage of Slovene firms using IMTs. In all three analysed years, they assigned the highest IMT potential to ICS followed by FCR. The perceived utilities were higher in 2011 than in 2008 and the differences in the perceived utility potentials between 2008 and 2011 were statistically significant for all areas, except for 
$\mathrm{KM}$ at $p<0.01$. It is quite possible that during the economic crisis Slovene top managers and product development managers have become aware of the IMT potential to the NPD effectiveness and especially to meeting customers' needs.

After having discovered that the utility potential of IMTs was an insignificant barrier to IMT usage, our research was directed towards the respondents' experience about the utility potential of those IMTs which mean frequency of usage was higher than 3.0 (a selection from Table 4). The results are presented in Table 6 . They assigned the highest utility potential to FMEA with a mean utility of 6.21. Regarding their experience, FMEA provided the most useful information about FCR and ICS amongst all in the survey included IMTs. FMEA was followed by QFD with mean utility of 6.05 . This technique had the greatest potential for SDT. VA had the highest potential to KM. The usage of IMTs has mostly contributed to an ICS (mean $=6.08)$, and a RFC (mean $=5.49)$.

The next step analysed the importance of other potential barriers to IMT usage in Slovene firms.

Table 6. Utility potential of selected IMTs (10-point scale ranging)

\begin{tabular}{lccccc}
\hline IMT & SDT & FCR & ICS & KM & Mean \\
\hline FTA & 3.43 & 5.86 & 5.14 & 4.14 & 4.64 \\
\hline FMEA & 4.90 & 7.22 & 7.10 & 5.60 & 6.21 \\
\hline QFD & 5.60 & 5.60 & 6.80 & 6.20 & 6.05 \\
\hline VA & 3.78 & 3.89 & 5.67 & 6.71 & 5.01 \\
\hline TC & 4.20 & 3.00 & 5.50 & 3.80 & 4.13 \\
\hline SPC & 3.75 & 7.38 & 6.25 & 4.86 & 5.56 \\
\hline Mean & 4.28 & 5.49 & 6.08 & 5.22 & \\
\hline
\end{tabular}

We investigated the following barriers: the availability of information needed (ANI) in IMT implementation, IMT complexity (TEC), needed coaching and training of employees (CTN) due to the lack of IMT competences, and problems in implementing the IMT results (ITR). In the 2003 analysis, the respondents were asked to choose one out of four offered barriers that represented the most important barrier to IMT usage in their firms: ANI $26 \%$, TEC $33 \%$, CTN $11 \%$, and ITR $30 \%$. In 2008 and 2011, the importance of barriers was measured on a 10-point scale ranging from 1 - 'not at all important' to 10 - 'very important'. Results for 2008 and 2011 are presented in Table 7.

Technique complexity has been reported as the most important barrier to IMT usage as $33 \%$ of respondents found it to be the greatest obstacle to using IMTs in innovation process in 2003, and the highest mean importance also belonged to this barrier in 2008 and 2011. The importance of other barriers differed in 2003 or 2008 and 2011. The problems with an implementation of IMT results were recognized as the second most important barrier in 2003, the needed coaching and training for IMT usage was the second most important barrier in 2008, but in 2011 the lack of available information needed for the IMT usage was found as the second most important barrier.

Table 7. Barriers to IMT usage

\begin{tabular}{lll}
\hline Barriers & 2008 & 2011 \\
\hline ANI & 5.00 & 6.10 \\
\hline TEC & 5.56 & 6.27 \\
\hline CTN & 5.22 & 5.94 \\
\hline ITR & 4.61 & 5.50 \\
\hline
\end{tabular}

\section{DISCUSSION}

The customers' requirements have played very important role as they found as the most important trigger of NPD in Slovene firms. In 2008, the customers' requirements were mainly met by incremental changes of products. However, the shift to radical product changes was noticed in 2011. The economic crisis and keener competition have probably forced Slovene firms to adapt to new economic circumstances by development of more radically new products. It confirms the finding of the Organisation for economic co-operation and development (OECD) (2010) that innovations are essential for countries and firms that are to recover from the economic downturn and thrive in today's highly competitive global economy.

FMEA was the most used IMT in Slovene firms. Less than one third of Slovene firms used other IMTs. The percentage of Slovene firms using IMTs was lower than was the percentage of firms included in the study of Barczak et al. [13].

The highest percentage of Slovene firms using FMEA and FTA shows that the IMT usage has been closely connected with their main objective NPD to better meet customers' needs. The comparison of data about the IMT usage in 2003 and 2011 shows the stability in the usage of FMEA and QFD as well as the substantial increase in FTA and TRIZ usage. The finding that substantially more Slovene firms used FMEA than QFD shows the higher popularity of FMEA which is the guardian to the voice of the engineer. The increasing number of Slovene firms with competences and usage of TRIZ could be a signal that Slovene firms are becoming aware of the importance that systematic way of managing idea generation has on new product success. The shift 
from the most frequently usage of SPC in 2008 to TC in 2011 in non-profitable firms could be a sign that innovations and the effectiveness of NPD become more and more important objectives also in the nonprofitable firms.

Profitable Slovene firms have used IMTs more frequently than non-profitable firms. Barczak et al. [13] stated the similar finding also for firms included in their study thus forming the conclusion that IMT usage contributes to the effectiveness and efficiency of innovation processes, and consequently to the new product success. Therefore, the IMT competences and usage can be taken as an opportunity especially for non-profitable Slovene firms to improve the effectiveness and efficiency of their innovation processes.

The data comparison between 2008 and 2011 shows the increasing trend in IMT competence in Slovene firms which could be a consequence of increasing trend of perceived IMT utility as well as the consequences of economic crisis which forces Slovene firms to introduce more radical innovations in the shorter time.

The perceived utility potential of IMTs cannot be taken as the reason for current state of competences and IMT use in Slovene firms. Technique complexity was the most important barrier to IMT use in the period from 2003 to 2011 in Slovene firms. Technique complexity represents a serious barrier to IMT use especially in small firms. This finding is similar to finding of Libutti [28] who revealed that an IMT, to be usable by a small company, must be simple to explain to the personnel and must quickly produce visible effects. A similar conclusion was made by Barczak et al. [13]. The rank order of other reasons fluctuated during the investigated period. The second most important barrier was the implementation of technique results in 2003; in 2008 it was needed coaching and training of employees to be able to use IMTs; and in 2011 it was the lack of needed data for IMT usage. The rank order of these barriers can be also explained by Dermol and Drev who found that the problem in Slovene industry is not the number of highly-educated people but rather their skills and knowledge about IMTs obtained during their education [29]. It is very important that management insists on introducing and perfecting individual methods and techniques, and provides continuous on-job training for their staff. Using training of employees responsible for NPD will probably remove major barriers to use IMTs in Slovene firms. Universities can help to remove these barriers by adding IMT competence in their curriculum.

\section{REFERENCES}

[1] Adams, R., Bessant, J., Phelps, R. (2006). Innovation management measurement: A review. International Journal of Management Reviews, vol. 8, no. 1, p. 2147, DOI:10.1111/j.1468-2370.2006.00119.x.

[2] Trott, P. (2008). Innovation Management and New Product Development (4th ed.). Pearson Education Limited, Essex.

[3] Benedicic, J., Zavbi, R., Duhovnik, J. (2012). Development of a new method of searching a new product development opportunity. Tehnički vjesnik Technical Gazette, vol. 19, no. 4, p. 759-767.

[4] Fagerberg, J., Mowery, D.C., Nelson, R.R. (2006). The Oxford Handbook of Innovation. Oxford University Press, Oxford, DOI:10.1093/ oxfordhb/9780199286805.001.0001.

[5] Novak, M. (2012). Computer aided decision support in product design engineering. Tehnički vjesnik - Technical Gazette, vol. 19, no. 4, p. 743-752.

[6] Christensen, C.M. (1997). The Innovator's Dilemma: When New Technologies Cause Great Firms to Fail. Harvard Business School Press, Boston.

[7] Christensen, C.M., Raynor, M.E. (2003). The Innovator's Solution: Creating and Sustaining Successful Growth. Harvard Business School Press, Boston.

[8] Bessant, J., Tidd, J. (2007). Innovation and Entrepreneurship. John Wiley \& Sons, Chichester.

[9] OECD. Key Findings, Ministerial report on the OECD Innovation Strategy - Innovation to strengthen growth and address global and social challenges, from http:// www.oecd.org/site/innovationstrategy, accessed on 2010-10-05.

[10] Krishnan, V., Ulrich, K.T. (2001). Product Development Decisions: A Review of the Literature. Management Science, vol. 47, no. 1, p. 1-21, DOI:10.1287/ mnsc.47.1.1.10668.

[11] Chao, L.P., Ishii, K. (2004). Design process errorproofing: project quality function deployment. Proceedings of DETC'04. ASME Design Engineering Technical Conferences, Salt Lake City.

[12] Cooper, R.G. (2000). Doing it right winning with new products. Ivey Business Journal, vol. 64, no. 6, p. 5463.

[13] Barczak, G., Griffin, A., Kahn, K.B. (2009). Perspective: Trends and drivers of success in NPD practices: Results of the 2003 PDMA best practices study. Product Innovation Management, vol. 26, no. 1, p. 3-23, DOI:10.1111/j.1540-5885.2009.00331.x.

[14] Büyüközkan, G., Dereli, T., Baykasoğlu, A. (2003). A survey on the methods and tools of concurrent new product development and agile manufacturing. Journal of Intelligent Manufacturing, vol. 15, no. 6, p. 731-751, DOI:10.1023/B:JIMS.0000042660.77571.81.

[15] Shepherd, C., Ahmed, P.K. (2000). NPD frameworks: a holistic examination. European Journal of 
Innovation Management, vol. 3, no. 3, p. 160-173, DOI:10.1108/14601060010341166.

[16] Milosavljevic, B.B., Congradac, V.D., Velickovic, V.M., Prebiracevic, B.V. (2012). Business process management in sustainable property/asset management by using the TotalObserver. Thermal Science, vol. 16, Supplement 1, p. S269-S279, DOI:10.2298/ TSCI120223077M.

[17] Ayadi, M., Costa Affonso, R., Cheutet, V., Masmoudi, F., Riviere, A., Haddar, M. (2013). Conceptual model for management of digital factory simulation information. International Journal of Simulation Modelling, vol. 12, no. 2, p. 107-119, DOI:10.2507/ IJSIMM12(2)4.233.

[18] Rihar, L., Kusar, J., Gorenc, S., Starbek, M. (2012). Teamwork in the simultaneous product realisation. Strojniški vestnik - Journal of Mechanical Engineering, vol. 58, no. 9, p. 534-544, DOI:10.5545/ sv-jme.2012.420.

[19] Phaal, R., Farrukh, C.J.P., Probert, D.R. (2006). Technology management tools: concept, development and application. Technovation, vol. 26, no. 3, p. 336344, DOI:10.1016/j.technovation.2005.02.001.

[20] Kohn, S., Hüsig, S. (2006). Potential benefits, current supply, utilization and barriers to adoption: An exploratory study on German SMEs and innovation software. Technovation, vol. 26, no. 8, p. 988-998, DOI:10.1016/j.technovation.2005.08.003.

[21] Hidalgo, A., Albors, J. (2008). Innovation management techniques and tools: a review from theory and practice. $R \& D$ Management, vol. 38, no. 2, p. 113-127, DOI:10.1111/j.1467-9310.2008.00503.x.

[22] Palacios, T.M.B., González, F.J.M. (2002). Assessing the validity of new product development techniques in Spanish firms. European Journal of Innovation Management, vol. 5, no. 2, p. 98-106, DOI:10.1108/14601060210428195.
[23] Prasad, B. (2000). Converting computer-integrated manufacturing into an intelligent information system by combining CIM with concurrent engineering and knowledge management. Industrial Management and Data Systems, vol. 100, no. 7, p. 301-316, DOI:10.1108/02635570010349104.

[24] Bozickovic, R., Radosevic, M., Cosic, I., Sokovic, M., Rikalovic, A. (2012). Integration of simulation and lean tools in effective production systems - Case study. Strojniški vestnik - Journal of Mechanical Engineering, vol. 58, no. 11, p. 642-652, DOI:10.5545/ sv-jme.2012.387.

[25] Smew, W., Young, P., Geraghty, J. (2013). Supply chain analysis using simulation, Gaussian process modelling and optimisation. International Journal of Simulation Modelling, vol. 12, no. 3, p. 178-189, DOI:10.2507/ IJSIMM12(3)4.239.

[26] Scozzi, B., Garavelli, C. (2005). Methods for modelling and supporting innovation processes in SMEs. European Journal of Innovation Management, vol. 8, no. 1, p. 120-137, DOI:10.1108/14601060510578619.

[27] Liu, H.-C., Liu, L., Liu, N. (2013). Risk evaluation approaches in failure mode and effects analysis: A literature review. Expert systems with applications, vol. 40, no. 2, p. 828-838, DOI:10.1016/j.eswa.2012.08.010.

[28] Libutti, L. (2000). Building competitive skills in small and medium-sized enterprises through innovation management techniques: overview of an Italian experience. Journal of Information Science, vol. 26, no. 6, p. 413-419.

[29] Dermol, V., Drev, D. (2011). Inženirstvo in z njim povezani dejavniki tehnološkega razvoja (Engineering and Associated Factors of Technological Development). Naše gospodarstvo (Our Economy), vol. 57, no. 5-6, p. 63-75. 